\title{
Picoplankton Dynamics and Their Trophic Roles in the Microbial Food-Web Processes in the Southern East China Sea Upwelling Region During Summer
}

\author{
An-Yi Tsai ${ }^{1, *}$, Gwo-Ching Gong ${ }^{1,2,3}$, Kuo-Ping Chiang ${ }^{1,2}$, Pei-Jung Tsai ${ }^{1}$, and Chien Fu Chao ${ }^{1}$ \\ ${ }^{1}$ Institute of Marine Environmental Chemistry and Ecology, National Taiwan Ocean University, Keelung, Taiwan, \\ Republic of China \\ ${ }^{2}$ Center of Excellence for the Oceans, National Taiwan Ocean University, Keelung, Taiwan, Republic of China \\ ${ }^{3}$ Taiwan Ocean Research Institute, National Applied Research Laboratories, Taipei, Taiwan, Republic of China
}

Received 9 August 2013, accepted 15 January 2014

\begin{abstract}
We monitored the abundance and biomass of nanoflagellates and their potential prey, heterotrophic bacteria, and Synechococcus spp. five times during the summers in 2010 and 2011. We used size-fractionation to measure growth and grazing rates of heterotrophic bacteria and Synechococcus spp. Temporal changes in surface water chlorophyll $a(\mathrm{Chl} a)$ concentrations during our study were caused by an influx of nutrient-rich water upwelling into the surface water. The bacterial growth rates ranged from 0.01 to $0.08 \mathrm{~h}^{-1}$ and grazing rates from 0 to $0.06 \mathrm{~h}^{-1}$. Bacterial growth rate had a positive relationship with $\mathrm{Chl} a$ concentration. Furthermore, growth and grazing rates of Synechococcus spp. ranged from 0.01 to 0.09 and 0 to $0.02 \mathrm{~h}^{-1}$, respectively. During the study period about $68 \%$ of the bacterial production and $41 \%$ of the Synechococcus spp. production was grazed by nanoflagellates in the southern East China Sea upwelling region, thus, a large fraction of bacterial biomass is transferred to higher trophic levels via nanoflagellate grazing.
\end{abstract}

Key words: Upwelling, Nanoflagellate, East China Sea

Citation: Tsai, A. Y., G. C. Gong, K. P. Chiang, P. J. Tsai,and C.F. Chao, 2014: Picoplankton dynamics and their trophic roles in the microbial food-web processes in the southern East China Sea upwelling region during summer. Terr. Atmos. Ocean. Sci., 25, 435-448, doi: 10.3319/TAO.2014.01.15.01(Oc)

\section{INTRODUCTION}

Ubiquitous heterotrophic bacteria dominate the mineralization of dissolved organic matter (DOM) in the sea (Azam and Hodson 1977). It is generally agreed that bacteria in the open ocean derive their nutrition from DOM originally derived from phytoplankton. In the pelagic zones, primary production is generally thought to be sustained more by the recycling of growth-limiting nutrients than by the diffusion of nutrients through the pycnocline. In upwelling systems, autochthonously produced DOM is an important component of $\mathrm{C}$ and $\mathrm{N}$ budgets (Hill and Wheeler 2002; Wetz and Wheeler 2004), and bacterial abundance is closely related to the upwelling cycle and production of phytoplankton (Bak and Nieuwland 1993; Wetz and Wheeler 2004). For instance, in the upwelling area off Concepción, central Chile, bacterial production represents $18.9-28.6 \%$ of the primary production. Significant correlations have been

\footnotetext{
* Corresponding author

E-mail:anyitsai@mail.ntou.edu.tw
}

found between primary and bacterial production as well as between bacterial abundance and chlorophyll $a(\mathrm{Chl} a)$ (Cuevas et al. 2004).

Picophytoplankton contributes significantly to the plankton biomass and productivity in oligotrophic regions of the ocean (Gradinger et al. 1992; Iriarte and Purdie 1994; Agawin and Agustí 1997). In oceanic upwelling systems, larger algal species, especially diatoms, often dominate the phytoplankton community (Lassiter et al. 2006). However, phytoplankton of smaller size fractions have been observed to respond faster to the upwelling events than those of larger size fractions by Lips and Lips (2010). Likewise, Synechococcus spp. has been found to vary positively with Chl $a$ concentrations and dominate the phytoplankton community's response in a coastal upwelling system (Garrison et al.2000; Tsai et al. 2010b). However, the factors that regulate size structure of phytoplankton under different trophic conditions are still being debated (Agawin et al. 2000; Echevarría et al. 2009). For instance, in the Oregon coastal upwelling ecosystem, Sherr et al. (2005) found a negative relationship 
between integrated abundance of picophytoplankton cells and $\mathrm{Chl} a$ concentrations.

Nanoflagellates play an important role in microbial food webs, where they are a major cause of mortality for smaller primary producers (e.g., Synechococcus spp.) as well as heterotrophic bacteria (Sanders et al. 2000; Sherr and Sherr 2002; Tsai et al. 2005). Highly productive upwelling systems are commonly characterized as having short food chains composed of large-sized phytoplankton, zooplankton and pelagic fish (Ryther 1969). However, the microbial components of food webs are ubiquitous with important features of both oligotrophic and eutrophic systems, including seasonally variable upwelling areas (Cuevas et al. 2004; Worden et al. 2004; Vargas et al. 2007). Protists in upwelling regions can be an important component of the plankton community (Neuer and Cowles 1994; Vargas and González 2004). Cuevas and Morales (2006) observed that, in the northern Humboldt Current System upwelling area, for example, nearly $100 \%$ of the bacterial production and $17 \%$ of the cyanobacterial production is grazed by nanoflagellates in the water column.

Extending from the coast of mainland China to the offshore region northeast of Taiwan, the southern East China Sea (ECS) is a highly dynamic region because of the interaction of different water types, including China Coastal Water, Taiwan Current Warm Water and Upwelling Water (Gong et al. 1996). The upwelling events are particularly important in the pelagic ecosystem of the southern ECS, because the input of nutrients into the euphotic zone during summer makes it possible for an increase in microbial biological production when an oligotrophic situation is expected. In the southern ECS, hydrographic and nutrient conditions regulate the phytoplankton biomass and primary production (Liu et al. 1995). Previous studies have shown that microbial populations are affected by environmental factors in the ECS (Jiao et al. 2005; Tsai et al. 2010a; Tsai et al. 2011). There are few ecological studies on the distributions of microbial populations in the upwelling region of southern ECS. In this investigation, we studied summertime dynamics and the trophic role of the nanoflagellate assemblage in the microbial food web of an upwelling region of the southern ECS. To do this, we monitored the cell abundance and biomass of nanoflagellates in this region for two years. In addition, using size-fractionation, we measured the growth and grazing rates of the picoplankton nanoflagellate prey (heterotrophic bacteria and Synechococcus spp.).

\section{MATERIAL AND METHODS}

\subsection{Sampling}

We collected samples from 13 stations in the southern ECS along an inshore-offshore transect on board the R/V Ocean Researcher II (Fig. 1). Samples were collected during five short cruises: two in August 2010 (2 - 5 August and 23 - 25 August 2010) and three in 2011 (8 - 10 June, 1 - 3 August, and 4 - 6 September). The hydrography along this transect is fairly well-described (Gong et al. 1996; Chiang et al. 1997) and it is known to be influenced by different water masses, including China Coastal Water, Taiwan Current Warm Water and Upwelling Water (Gong et al. 1996). Seawater was collected using a SeaBird CTD-General Oceanic Rosette assembly with 20 L Go-Flo bottles at different water depths. Temperature and salinity was measured in depth profiles with a SeaBird CTD.

For Ch1 $a$ analysis $1 \mathrm{~L}$ water samples were first filtered (25 mm GF/F) and stored at $-20^{\circ} \mathrm{C}$ in darkness. Samples were then extracted in cold $90 \%$ acetone in darkness for $24 \mathrm{~h}$ before analysis using a Turner Design Model 10-AU-005

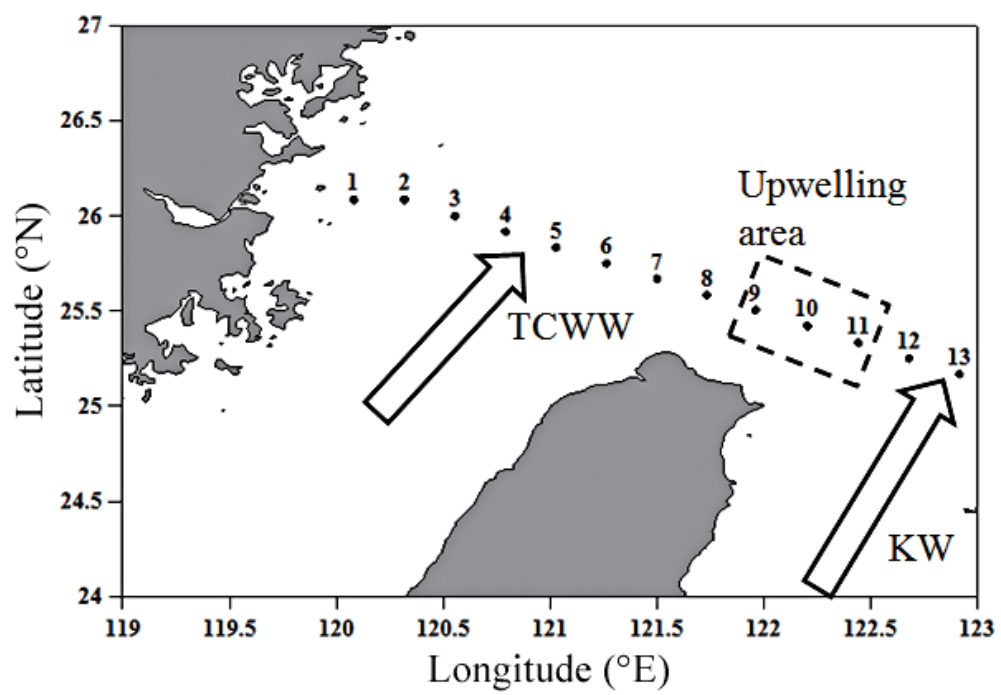

Fig. 1. Location of sampling site in the southern East China Sea. TCWW: Taiwan Current Warm Water, KW: Kuroshio Water. The region between stations 9 and 11 is the upwelling system. 
fluorometer (Parsons et al. 1984). Water samples for nutrient analyses were placed in clean $100-\mathrm{mL}$ polypropylene bottles and frozen immediately with liquid nitrogen. Nitrate was reduced to nitrite with a cadmium wire, being activated with copper sulfate solution, and was then analyzed with a selfdesigned flow injection analyzer (Gong et al. 1992). Primary productivity (PP) in surface waters was measured by ${ }^{14} \mathrm{C}$ assimilation method (Parsons et al. 1984). Water samples were pre-screened through $200 \mu \mathrm{m}$ woven mesh (Spectrum) to remove large organisms and particles. Next, two light and one dark $250 \mathrm{~mL}$ clean polycarbonate bottles (Nalgene) were filled with filtrate and inoculated with $10 \mu \mathrm{Ci} \mathrm{NaH}{ }^{14} \mathrm{CO}_{3}$. Primary productivity samples were incubated on deck from dawn to dawn and cooled with running seawater. Duplicate light bottles from a given depth were covered with several layers of nylon stockings to simulate local light penetration.

\subsection{Bacteria, Synechococcus Spp., Heterotrophic Nanoflagellates (HNF) and Pigmented Nanoflagellates (PNF)}

To count bacteria, Synechococcus spp., HNF and PNF, we fixed $50 \mathrm{ml}$ water samples with glutaraldehyde to a final concentration of 1\% (Christaki et al. 1999; Sanders et al. 2000), with $1-2$ or $20 \mathrm{~mL}$ filtered onto 0.2 or $0.8 \mu \mathrm{m}$ black Nuclepore filters for picoplankton (bacteria and Synechococcus spp.) and nanoflagellates, respectively. Samples were stained with DAPI at a final concentration of $1 \mu \mathrm{g} \mathrm{mL}^{-1}$ (Porter and Feig 1980). PNF and HNF were counted based on the presence or absence of chlorophyll autofluorescence using a separate filter set optimized for chlorophyll or DAPI under a 1000X epifluorescence microscope (Nikon-Optiphot-2). Bacteria and HNF were identified by their blue fluorescence under UV illumination. Synechococcus spp. and PNF were identified by their orange and red autofluorescence under blue excitation light. To obtain reliable estimates of abundance, we counted 30 and 50 fields of view for bacteria and nanoflagellates, respectively.

\subsection{Growth and Grazing Estimates}

Using size-fractionation (Wright and Coffin 1984) we estimated heterotrophic bacteria and Synechococcus spp. growth and grazing rates near the upwelling area during the study period (Fig. 1). All water samples were collected from $5 \mathrm{~m}$ depth and used for the following size fractionations. Samples were treated twice to remove predators of different sizes. A $2-\mu \mathrm{m}$ pore size polycarbonate filter was used to remove bacteria and Synechococcus spp. predators, and a $10-\mu \mathrm{m}$ pore size polycarbonate filter was used to remove nanoflagellate predators. The size fractionation used for grazers $(<10 \mu \mathrm{m})$ was chosen based on previous studies at this site to eliminate ciliates but not nanoflagellates (Tsai et al. 2008). Each size fraction was then transferred into polycarbonate bottles to a volume of $125 \mathrm{~mL}$ (run in triplicate). The bottles were incubated in a water bath at in situ temperature and under natural light for $8 \mathrm{~h}$. At the beginning and end of each incubation period triplicate samples $(30 \mathrm{~mL})$ were taken to count pico- and nanoplankton as described above.

Growth rates $\left(\mu, \mathrm{h}^{-1}\right)$ of bacteria and Synechococcus spp. were calculated based on the results obtained from the $<2 \mu \mathrm{m}$ filtrates and those of nanoflagellates were calculated obtained from the $<10 \mu \mathrm{m}$ filtrates according to the equation:

$\mu=\left(\ln \mathrm{N}_{\mathrm{f}}-\ln \mathrm{N}_{\mathrm{i}}\right) /\left(\mathrm{T}_{\mathrm{f}}-\mathrm{T}_{\mathrm{i}}\right)$

where $\mathrm{N}_{\mathrm{i}}$ and $\mathrm{N}_{\mathrm{f}}$ are cell concentrations (cell $\mathrm{mL}^{-1}$ ) at the beginning $\left(\mathrm{T}_{\mathrm{i}}\right)$ and end $\left(\mathrm{T}_{\mathrm{f}}\right)$ of the incubation period in corresponding size fractions.

The grazing rates $\left(\mathrm{g}, \mathrm{h}^{-1}\right)$ of bacteria and Synechococcus spp. were calculated based on the results obtained from the difference between $<2$ and $<10 \mu \mathrm{m}$ filtrate growth rates.

$\mathrm{g}=\left(\mu_{2 \mu \mathrm{m}}\right)-\left(\mu_{10 \mu \mathrm{m}}\right)$

where $\mu_{2 \mu \mathrm{m}}$ and $\mu_{10 \mu \mathrm{m}}$ are the growth rates of bacteria and Synechococcus spp. in the $<2$ and $<10 \mu \mathrm{m}$ filtrates.

Microbial abundance was converted into carbon biomass $\left(\mathrm{B}, \mu \mathrm{g} \mathrm{C} \mathrm{L}^{-1}\right)$ using the following equation:

$\mathrm{B}=\mathrm{N} \times \mathrm{C}$

where $\mathrm{N}$ is cell density (cells $\mathrm{mL}^{-1}$ ) and $\mathrm{C}$ is estimated cell carbon content (fg C cell- ${ }^{-1}$ ).

Cell carbon was estimated using $15 \mathrm{fg} \mathrm{C}^{\text {cell }}{ }^{-1}$ for bacteria (Lee and Fuhrman 1987), $250 \mathrm{fg} \mathrm{C}^{-1 \mathrm{Cll}^{-1}}$ for Synechoc-

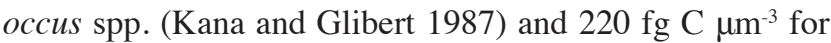
nanoflagellates (Børsheim and Bratbak 1987). Linear dimensions (length and width) of at least 20 cells were measured for each sample, with the cell volume calculated as an elliptical sphere to provide the cell volume.

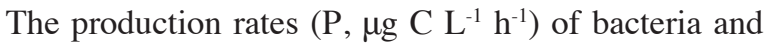
Synechococcus spp. were estimated from the $<2 \mu \mathrm{m}$ filtrates using the following equation:

$\mathrm{P}=\mu \times \mathrm{B}_{\mathrm{i}}$

where $\mathrm{B}_{\mathrm{i}}$ is the in situ cell biomass $\left(\mu \mathrm{g} \mathrm{CL}^{-1}\right)$ at the sampling time.

Furthermore, consumption rates $\left(\mathrm{G}, \mu \mathrm{g} \mathrm{C} \mathrm{L}^{-1} \mathrm{~h}^{-1}\right)$ of bacteria and Synechococcus spp. were estimated using the following equation:

$\mathrm{G}=\mathrm{g} \times \mathrm{B}_{\mathrm{i}}$ 


\section{RESULTS}

\subsection{Physical and Chemical Environment}

Water temperature ranged from $15.4^{\circ}$ to $29.9^{\circ} \mathrm{C}$, with higher values in the shallower layers (depth $<20 \mathrm{~m}$ ). Deeper temperature and salinity isolines indicated upwelling events occurred mainly between stations 9 and 11 (Fig. 2). Furthermore, surface nitrate concentrations generally decreased from the coastal station towards the offshore station (Figs. 3a, c, e, g, i). The upwelling events that occurred during all of the cruises brought high nitrate concentrations $(>10 \mu \mathrm{m})$ into the upper water column layers (Figs. 3a, c, e, g, i).

\subsection{Chl a, Bacterial, Synechococcus Spp. and Nanoflagellate Abundance Variations in the Surface Water}

Chl $a$ concentrations in the surface water ranged from 0.1 to $3.2 \mathrm{mg} \mathrm{m}^{-3}$ (Figs. $3 \mathrm{~b}, \mathrm{~d}, \mathrm{f}, \mathrm{h}, \mathrm{j}$ ). The concentrations and distributions of Chl $a$ appeared typical of those found in the ECS, with relatively high concentrations generally found in the coastal waters (Figs. 3b, d, f, h), except for the September 2011 cruise (Fig. 3j). High levels of Chl $a$ were usually observed at the outer fringe of the upwelling. The injections of nutrients by the upwelling water into the upper layers of stations 9 to 11 were followed by increases in Chl $a$ (maximum $>2.5 \mathrm{mg} \mathrm{m}^{-3}$ ) in September 2011 (Fig. $3 \mathrm{j}$ ), corresponding to the upwelling event that reached the shallowest depth in the water column.

The pico- and nanoplankton distributions from all depths were compared using data collected at stations 8 to 12 (Figs. 4 and 5). Bacterial and Synechococcus spp. abundance ranged from 0.3 to $30 \times 10^{5}$ cells $\mathrm{mL}^{-1}$ and from 0.5 to $25 \times 10^{4}$ cells $\mathrm{mL}^{-1}$, respectively, with higher values found in the shallow layers (depth $0-30 \mathrm{~m}$ ) in the upwelling area (Fig. 4). Furthermore, PNF abundance for all depths peaked between 10 and $60 \mathrm{~m}$ (Figs. 5a, c, e, g, i), the highest value being $>40 \times 10^{2}$ cells $\mathrm{mL}^{-1}$.

\section{Stations}
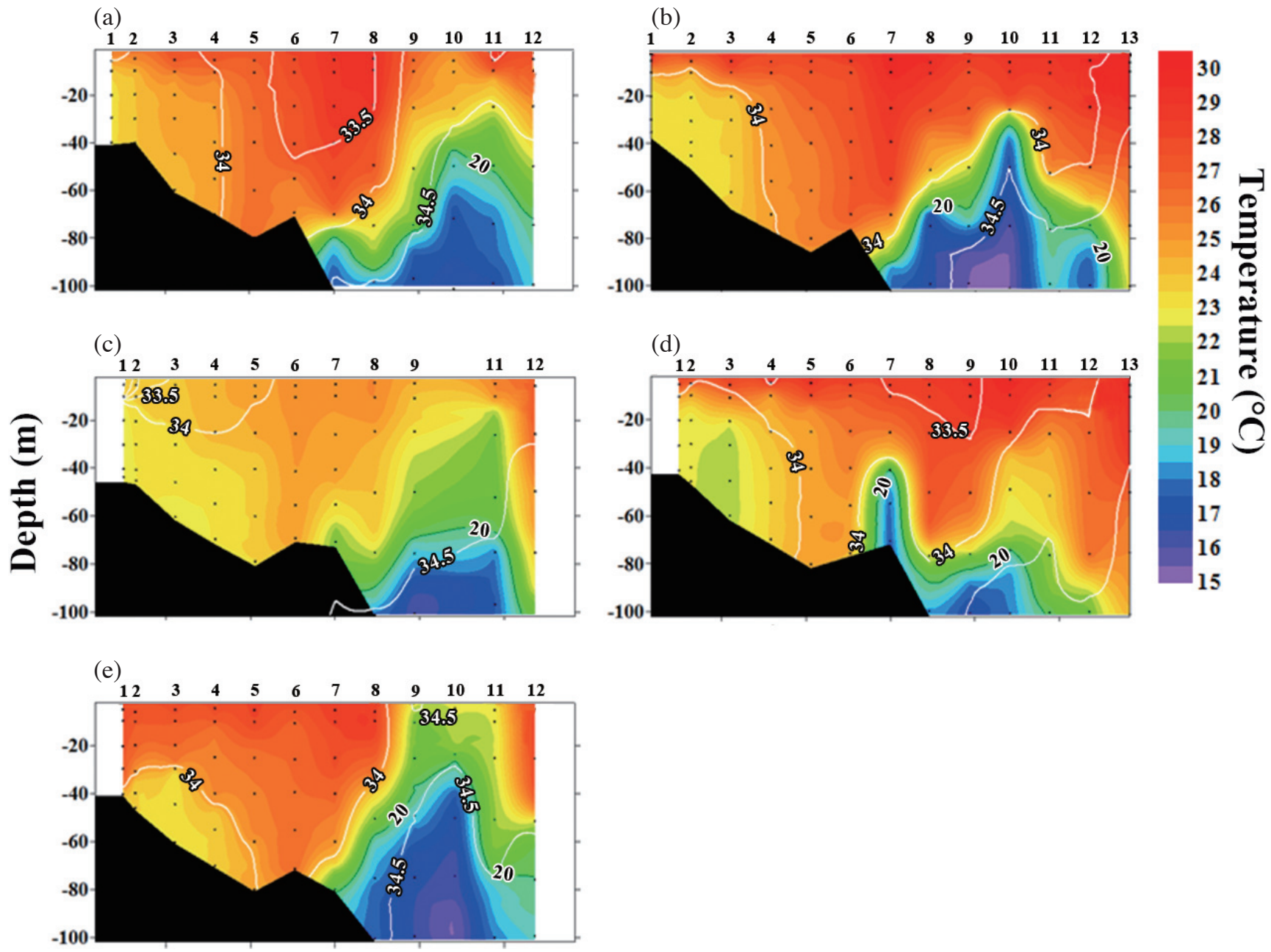

Fig. 2. Vertical distributions across the temperature and salinity (white line) during each of the cruises; (a) 2 - 5 August 2010 , (b) 23 - 25 August 2010, (c) 8 - 10 June 2011, (d) 1 - 3 August 2011 and (e) 4 - 6 September 2011. 
(a)

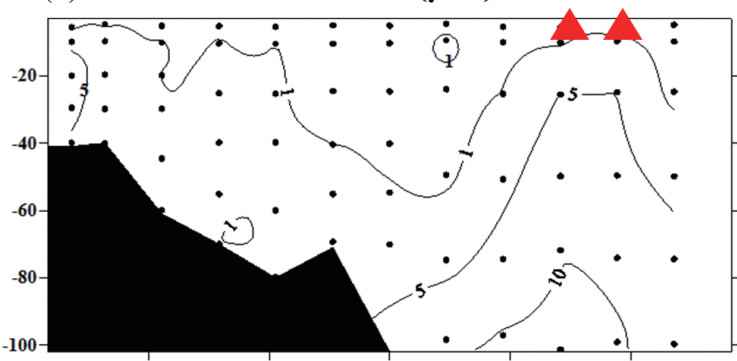

(c)

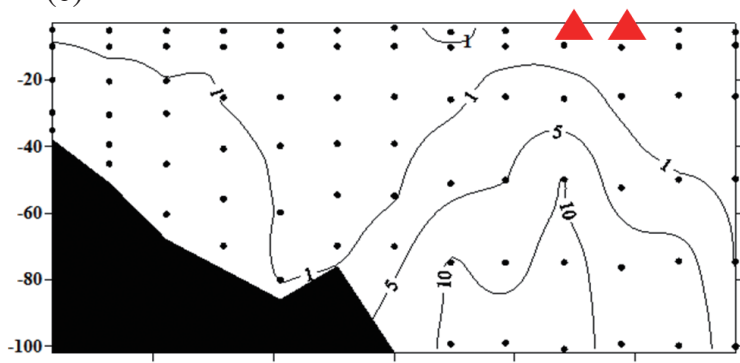

(e)

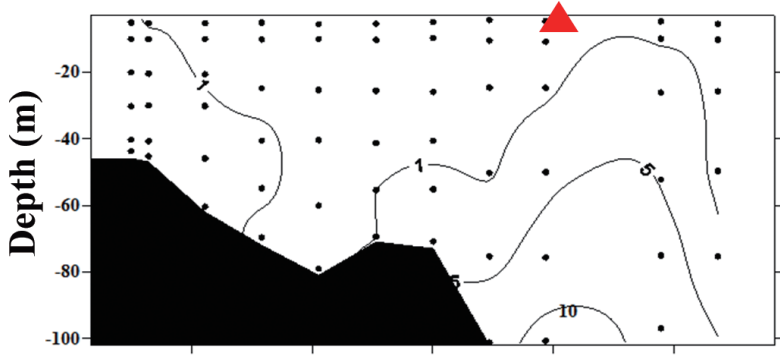

(g)

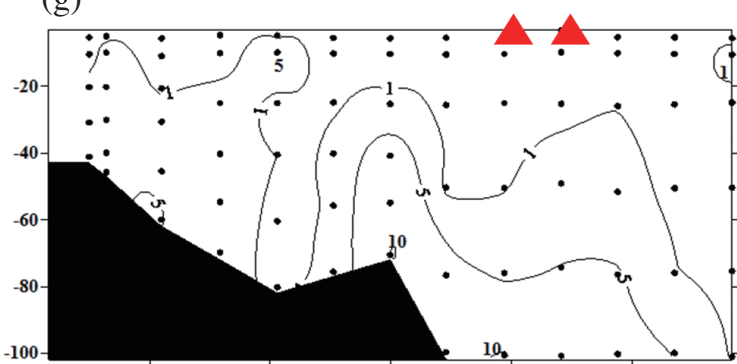

(i)

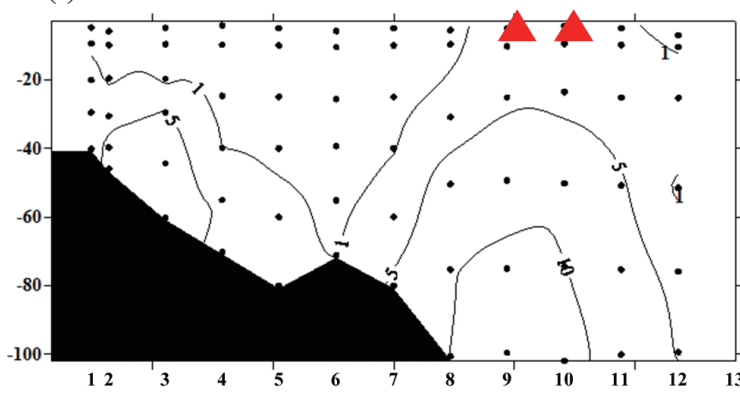

(b) Chl a $\left(\mathrm{mg} \mathrm{m}^{-3}\right)$

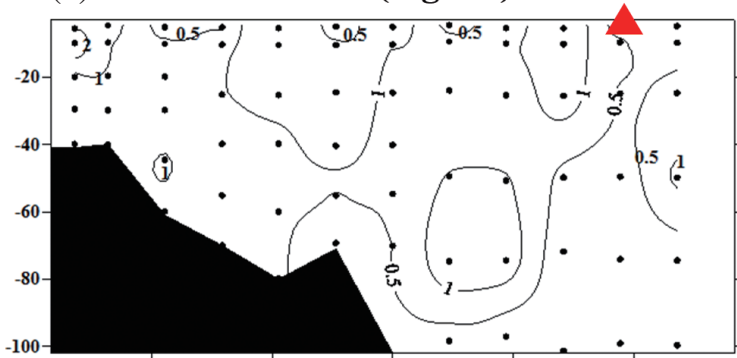

(d)

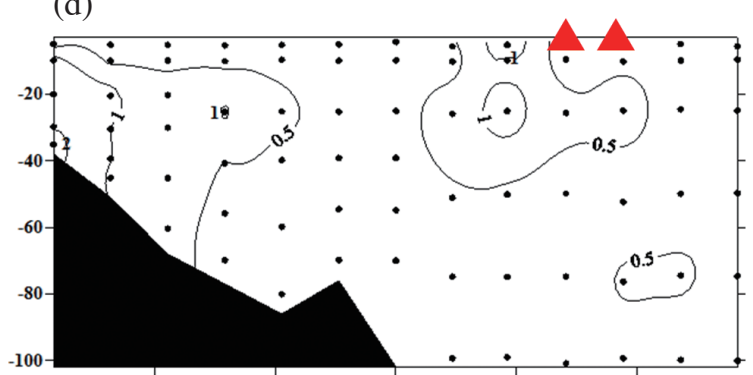

(f)

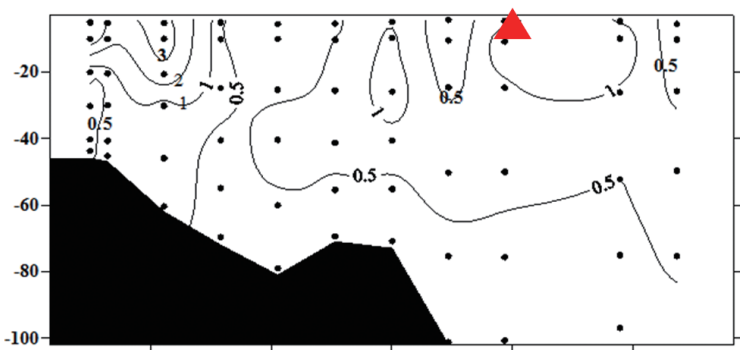

(h)

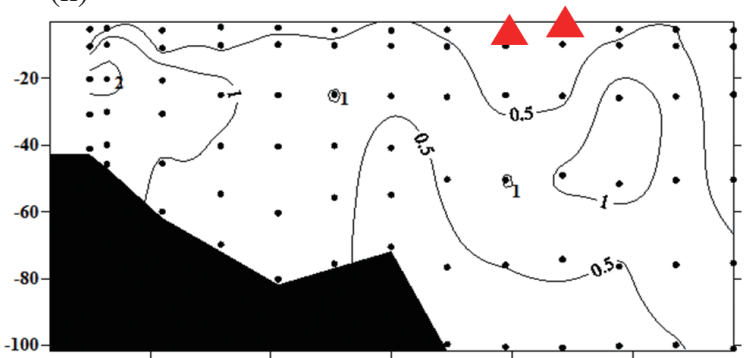

(j)

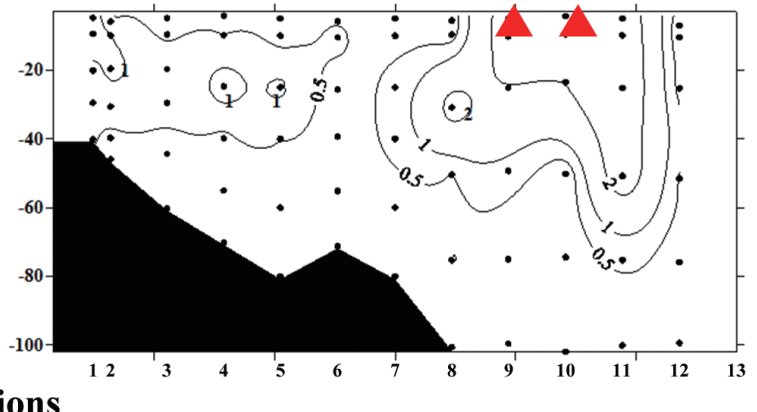

Fig. 3. Vertical variations across the transect in $\mathrm{NO}_{3}$ concentrations ( $\mu \mathrm{m}$, panel a - e) and Chl $a$ concentrations ( $\mathrm{mg} \mathrm{m}^{-3}$, panel $\mathrm{f}-\mathrm{j}$ ); (a) and (b): 2 - 5 August 2010, (c) and (d): 23 - 25 August 2010, (e) and (f): 8 - 10 June 2011, (g) and (h): 1 - 3 August 2011, and (i) and (j): 4 - 6 September 2011. 
bacteria

$\left(10^{5}\right.$ cells $\left.\mathrm{mL}^{-1}\right)$
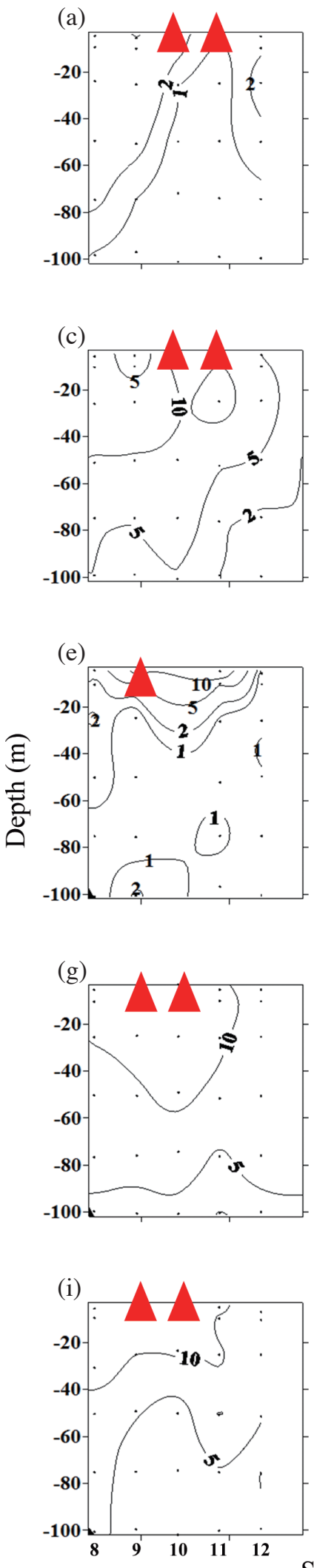

Synechococcus spp.

$\left(10^{4}\right.$ cells $\left.\mathrm{mL}^{-1}\right)$
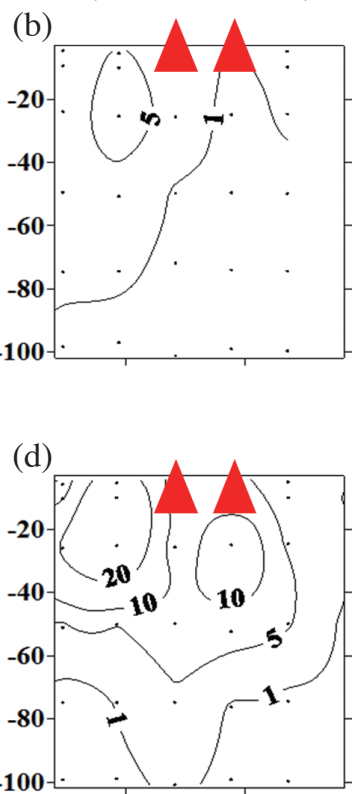

(f)
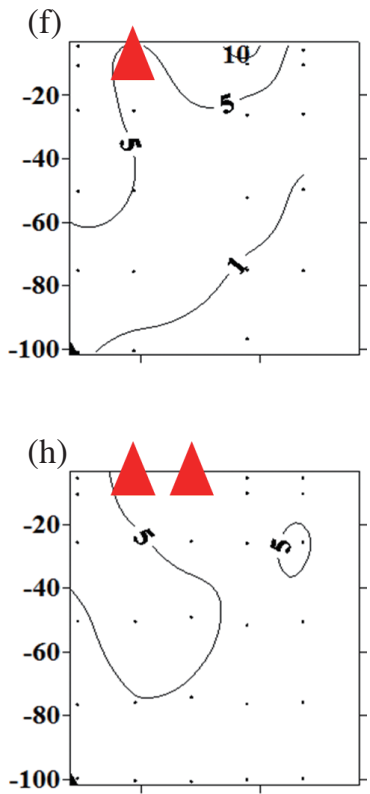

(j)

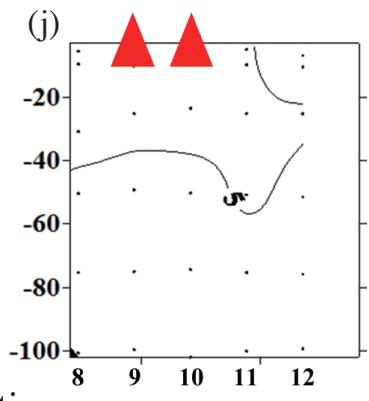

\section{Stations}

Fig. 4. Vertical variations across the transect in bacterial $\left(10^{5}\right.$ cells $\mathrm{mL}^{-1}$, panel a - e) and Synechococcus spp. abundance $\left(10^{4}\right.$ cells $\mathrm{mL}^{-1}$, panel $\left.\mathrm{f}-\mathrm{j}\right)$; (a) and (b): 2 - 5 August 2010, (c) and (d): 23 - 25 August 2010, (e) and (f): 8 - 10 June 2011,(g) and (h): 1 - 3 August 2011 , and (i) and (j): 4 - 6 September 2011. The red symbol ( $\Delta$ ) shows the sampling site for the incubation experiments. 
PNF

$\left(10^{2}\right.$ cells $\left.\mathrm{mL}^{-1}\right)$
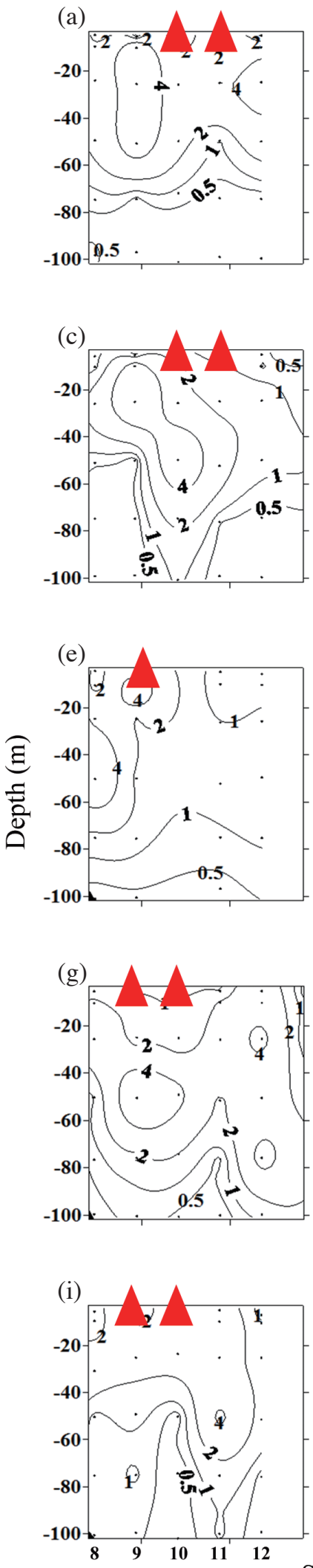

HNF

$\left(10^{2}\right.$ cells $\left.\mathrm{mL}^{-1}\right)$
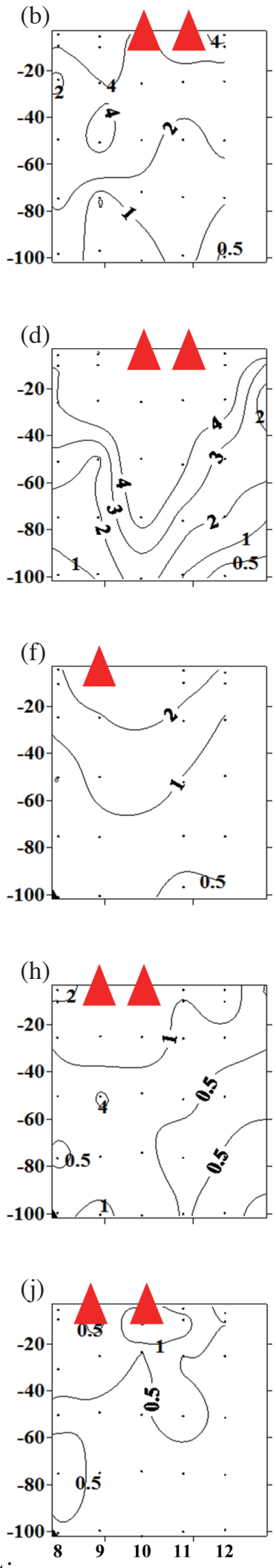

Fig. 5. Vertical variations across the transect in pigmented nanoflagellate (PNF, $10^{2}$ cells $\mathrm{mL}^{-1}$, panel a - e) and heterotrophic nanoflagellate abundance (HNF, $10^{2}$ cells mL $\mathrm{mL}^{-1}$, panel f - j); (a) and (b): 2 - 5 August 2010, (c) and (d): 23 - 25 August 2010, (e) and (f): 8 - 10 June 2011, (g) and (h): 1 - 3 August 2011, and (i) and (j): 4 - 6 September 2011. The red symbol ( $\mathbf{\Lambda}$ ) shows the sampling site for the incubation experiments. 
Analyzing the surface water $(\leq 10 \mathrm{~m})$ data set for the upwelling area, we found weakly significant positive relationships between bacterial, Synechococcus spp. and picoplankton biomass (bacterial and Synechococcus spp. biomass) and HNF biomass (bacteria: $r=0.49, p<0.05$; Synechococcus spp.: $r=0.57, p<0.05$; picoplankton: $r=0.6, p<0.05$ ) (Fig. 6), which suggested that the distributions of HNF was influenced by food availability.

\subsection{Pico- and Nanoflagellate Growth and Grazing Rates}

Nine experiments were prepared with seawater samples showing contrasting in situ temperature, salinity, $\mathrm{NO}_{3}, \mathrm{Chl} a$ and PP (Table 1). As can be seen in Table 2, a summary of pico- and nanoflagellate grazing and growth coefficient estimates based on data obtained by size-fractionation, the growth and grazing rates of bacteria ranged from 0.01 to $0.08 \mathrm{~h}^{-1}$ and from 0 to $0.06 \mathrm{~h}^{-1}$, respectively. The results showed a positive and significant correlation between $\mathrm{Chl} a$ concentrations and bacterial growth rates (Fig. 7). Furthermore, the growth rates of Synechococcus spp. varied between $0.01 \mathrm{~d}^{-1}$ and $0.09 \mathrm{~h}^{-1}$ during the summer period (Table 2).
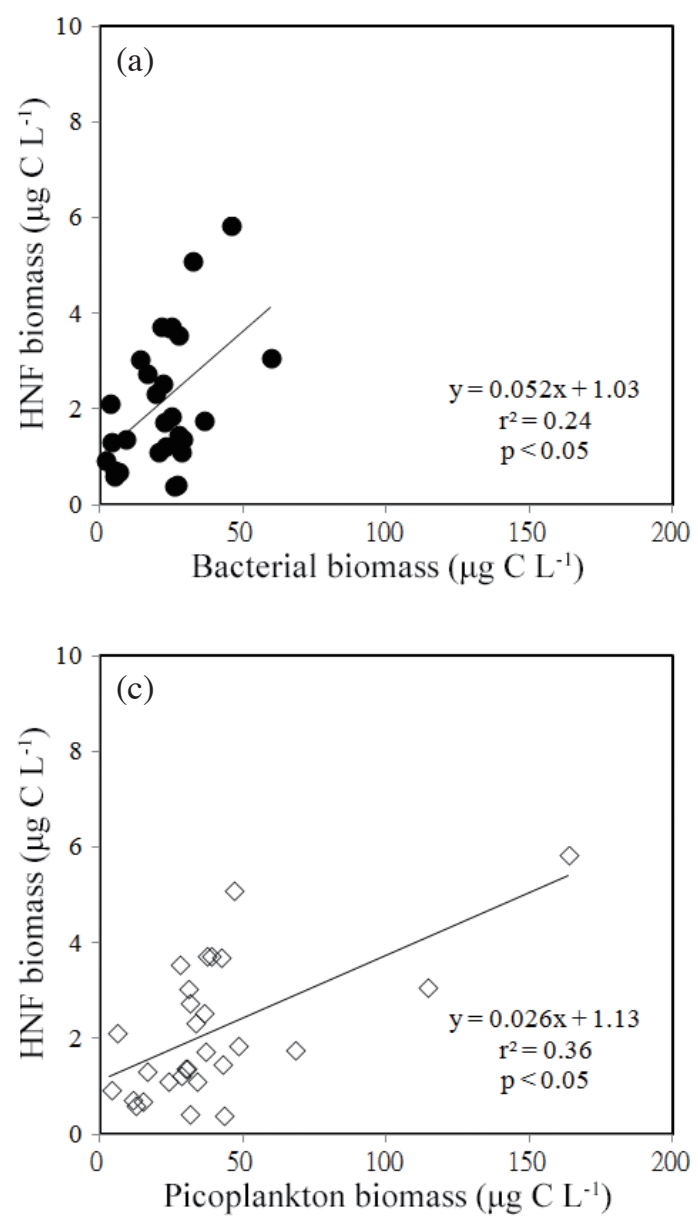

HNF and PNF growth rates ranged from 0 to $0.05 \mathrm{~h}^{-1}$ and from 0 to $0.06 \mathrm{~h}^{-1}$, respectively (Table 1). Prey growth was always higher than the nanoflagellate grazing pressure (68\% consumption of bacteria and $41 \%$ Synechococcus spp. production) (Fig. 8).

\section{DISCUSSION}

Temporal changes in the surface water Chl $a$ concentration during our study occurred as a result of an influx of nutrient-rich upwelled water into the surface water. The results showed a positive and significant correlation between Chl $a$ concentrations and bacterial growth rates. Previous studies suggest that a nutrient supply carried from deep waters into surface layers can enhance primary production (Bode et al. 1997; Lips and Lips 2010). Previous investigators of one upwelling area used the rate of primary production normalized by the Chl $a\left(\mathrm{mg} \mathrm{C} \mathrm{mg} \mathrm{Chl} a^{-1} \mathrm{~h}^{-1}\right)$ concentration as an indicator of phytoplankton growth potential (specific-rate of photosynthesis) (Hanson et al. 1986). The specific photosynthesis rates in this study ranged from 1.3 to $5.7 \mathrm{mg} \mathrm{C} \mathrm{mg} \mathrm{Chl} a^{-1} \mathrm{~h}^{-1}$, which are relatively low compared to other coastal upwelling

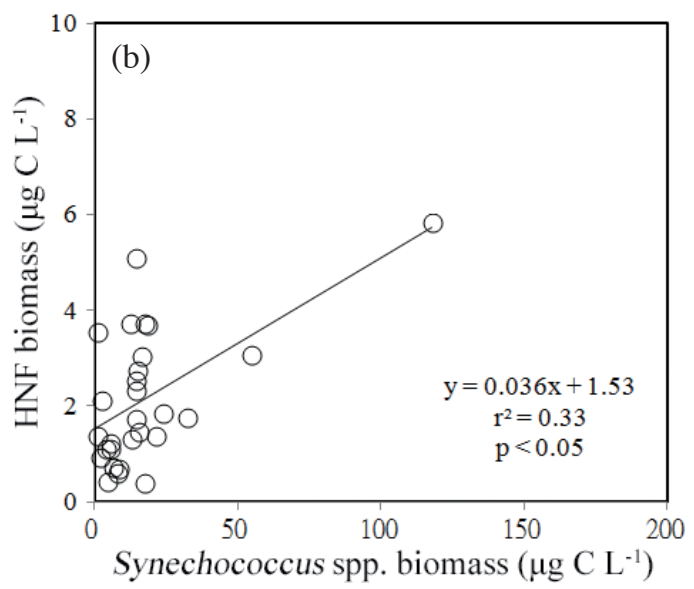

Fig. 6. Relationship between heterotrophic nanoflagellate (HNF) and bacterial biomass (a), Synechococcus spp. (b) and picoplankton biomass (bacteria + Synechococcus spp.) (c) for all surface water depths $(\leq 10 \mathrm{~m})$ in the upwelling region. 
Table 1. Physicochemical and biological characteristics in the upwelling region used for the experiments. PP: Primary productivity, - : no data.

\begin{tabular}{|c|c|c|c|c|c|c|}
\hline Sampling date & station (5m) & temperature $\left({ }^{\circ} \mathrm{C}\right)$ & salinity (psu) & NO3 $(\mu \mathrm{M})$ & Chl $a\left(\mathrm{mg} \mathrm{m}^{-3}\right)$ & 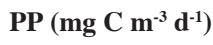 \\
\hline \multirow{2}{*}{2 - 5 August 2010} & St. 10 & 28.35 & 34.03 & 0.10 & 0.40 & - \\
\hline & St. 11 & 27.33 & 34.19 & 0.00 & 0.29 & 14.68 \\
\hline \multirow[t]{2}{*}{23 - 25 August 2010} & St. 10 & 28.90 & 33.72 & 0.29 & 0.39 & 53.39 \\
\hline & St. 11 & 29.73 & 33.71 & 0.00 & 0.36 & 29.75 \\
\hline 8 - 10 June 2011 & St. 9 & 24.57 & 34.31 & 0.00 & 0.72 & 22.49 \\
\hline \multirow[t]{2}{*}{1 - 3 August 2011} & St. 9 & 28.99 & 33.34 & 0.00 & 0.22 & 22.95 \\
\hline & St. 10 & 29.79 & 33.88 & 0.00 & 0.20 & - \\
\hline \multirow[t]{2}{*}{4 - 6 September 2011} & St. 9 & 22.09 & 34.47 & 3.06 & 2.66 & 148.75 \\
\hline & St. 10 & 22.62 & 34.30 & 1.42 & 2.33 & - \\
\hline
\end{tabular}

Table 2. Picoplankton and nanoflagellate growth and grazing rates for the size-fractionation experiments conducted in the upwelling region. sd: Standard deviation.

\begin{tabular}{|c|c|c|c|c|c|c|c|}
\hline \multirow[b]{2}{*}{ Sampling date } & \multirow[b]{2}{*}{ station $(5 \mathrm{~m})$} & \multicolumn{2}{|c|}{ bacteria } & \multicolumn{2}{|c|}{ Synechococcus spp. } & \multirow{2}{*}{$\begin{array}{c}\text { HNF } \\
\boldsymbol{\mu} \pm(\mathbf{s d})\left(\mathbf{h}^{-1}\right)\end{array}$} & \multirow{2}{*}{$\begin{array}{c}\text { PNF } \\
\mu \pm(\mathbf{s d})\left(h^{-1}\right)\end{array}$} \\
\hline & & $\boldsymbol{\mu} \pm(\mathbf{s d})\left(\mathbf{h}^{-1}\right)$ & $\mathbf{g} \pm(\mathbf{s d})\left(\mathbf{h}^{-1}\right)$ & $\boldsymbol{\mu} \pm(\mathbf{s d})\left(\mathbf{h}^{-1}\right)$ & $\mathrm{g} \pm(\mathbf{s d})\left(\mathbf{h}^{-1}\right)$ & & \\
\hline \multirow[t]{2}{*}{2 - 5 August 2010} & St. 10 & $0.04(0.02)$ & $0.01(0.01)$ & $0.04(0.02)$ & $0.01(0.01)$ & $0.03(0.04)$ & $0.06(0.03)$ \\
\hline & St. 11 & $0.04(0.03)$ & $0.02(0.02)$ & $0.04(0.03)$ & $0.01(0.01)$ & $0.04(0.03)$ & $0.05(0.04)$ \\
\hline \multirow[t]{2}{*}{23 - 25 August 2010} & St. 10 & $0.01(0.01)$ & $<0.005(0.005)$ & $0.03(0.03)$ & $<0.005(<0.005)$ & $0.03(0.03)$ & $0.02(0.02)$ \\
\hline & St. 11 & $0.02(0.02)$ & $0.01(0.02)$ & $0.05(0.02)$ & $0.02(0.02)$ & $0.04(0.05)$ & $0.03(0.04)$ \\
\hline 8 - 10 June 2011 & St. 9 & $0.08(0.04)$ & $0.06(0.03)$ & $0.03(0.02)$ & $0.02(0.03)$ & $0.05(0.03)$ & $0.03(0.03)$ \\
\hline \multirow[t]{2}{*}{1 - 3 August 2011} & St. 9 & $0.04(0.02)$ & $0.02(0.03)$ & $0.04(0.03)$ & $<0.005(0.01)$ & $0.01(0.02)$ & $0.05(0.04)$ \\
\hline & St. 10 & $0.02(0.02)$ & $<0.005(0.02)$ & $0.15(0.08)$ & $0.02(0.02)$ & $<0.005(0.01)$ & $0.04(0.05)$ \\
\hline \multirow[t]{2}{*}{4 - 6 September 2011} & St. 9 & $0.07(0.03)$ & $0.01(0.04)$ & $0.01(0.01)$ & $<0.005(0.01)$ & $<0.005(<0.005)$ & $<0.005(0.01)$ \\
\hline & St. 10 & $0.06(0.03)$ & $<0.005(0.01)$ & $0.09(0.06)$ & $0.013(0.02)$ & $<0.005(0.01)$ & $<0.005(0.01)$ \\
\hline
\end{tabular}

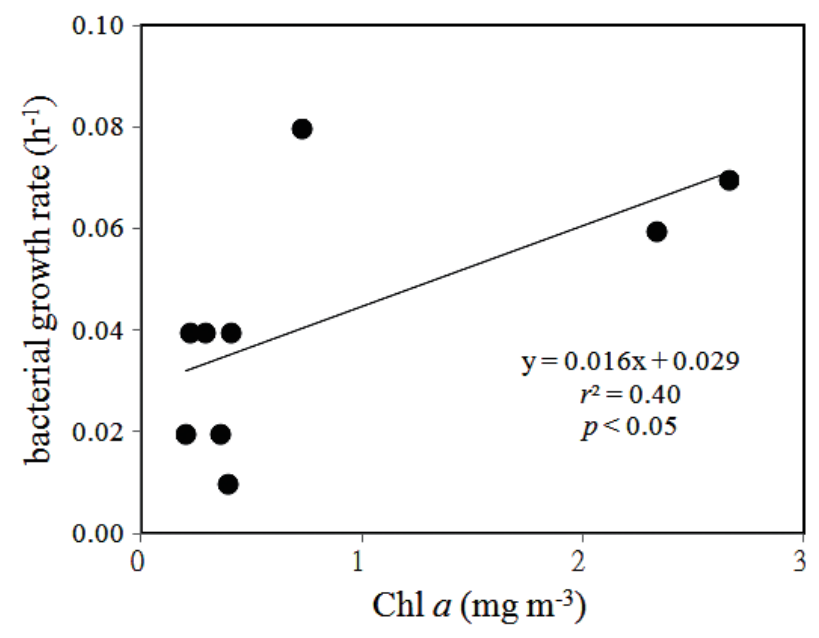

Fig. 7. Relationship between $\mathrm{Chl} a$ concentrations and bacterial growth rates during the study period. 

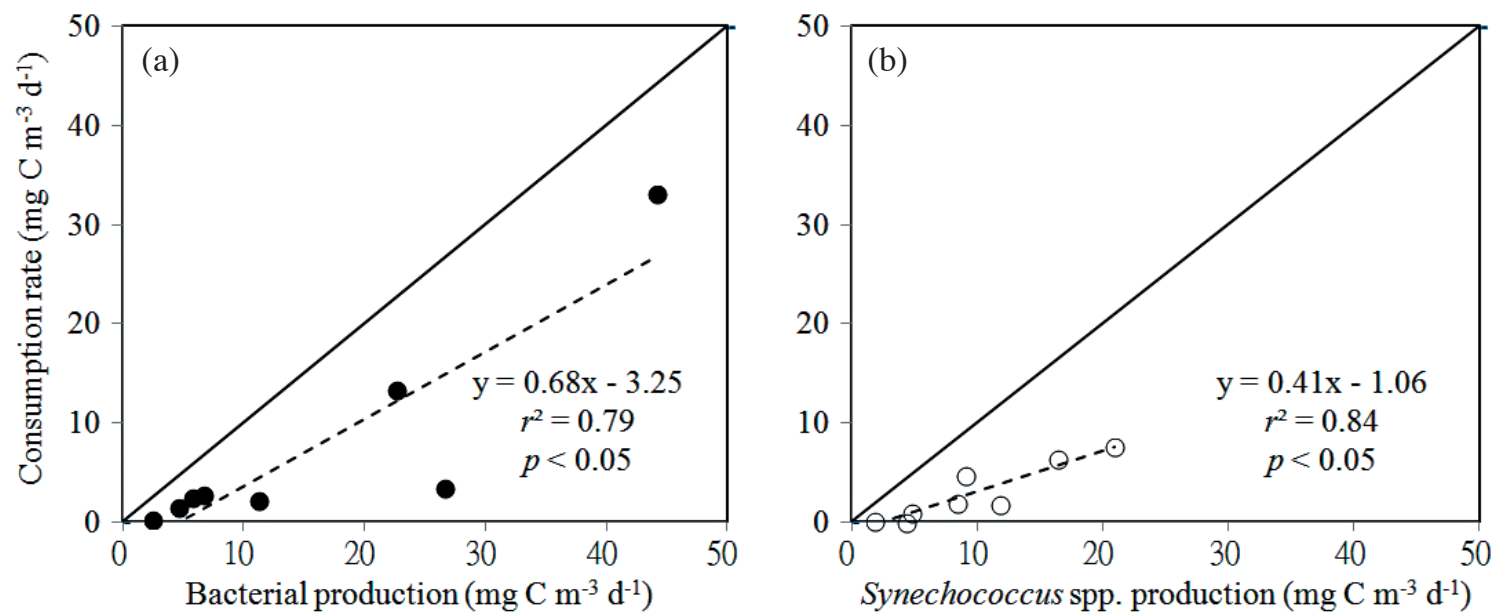

Fig. 8. Relationship between consumption rates and bacterial production (a) and Synechococcus spp. production (b). The solid line is 1:1 line.

studies (Malone and Neale 1981; Hanson et al. 1986). These low specific rates indicate that phytoplankton were growing slower and were in bad physiological condition in the surface water of the southern ECS. Harrison et al. (1981) showed that, in nutrient-stressed phytoplankton populations, once $\mathrm{NO}_{3}$ was depleted, specific rates declined to $<2 \mathrm{mg} \mathrm{C} \mathrm{mg} \mathrm{Chl} a^{-1} \mathrm{~h}^{-1}$. This result suggests that phytoplankton populations in the southern of ECS frequently shift between nutrient-limited and growth periods following an influx of upwelled waters. In addition, phytoplankton species composition and pigment composition within a species changes with irradiance levels (Falkowski 1981). However, in the current study light limitation seems unlikely since the $\mathrm{Chl} a$ and primary production values were measured in the surface waters during the summer. Phytoplankton growth is also controlled by factors other than light, such as nutrients and temperature. We expected a coupling of temperature and $\mathrm{Chl} a$ concentration, given the fact that phytoplankton growth increases with increasing temperature (Eppley 1972). However, we found a negative relationship between the temperature and $\mathrm{Chl} a$ concentrations (Fig. 9) $(r=-0.91, p<0.05)$. The results from our regression analyses suggest that the upwelling introduced low temperature waters and the nutrient supply associated with upwelling inputs to surface waters accounted for a significant fraction of variability in phytoplankton growth.

Primary production (DOC and POC) is a major source of readily available metabolites for oceanic bacteria (Azam et al. 1983). As has been found in the Humboldt Current System upwelling areas, an important proportion (up to $24 \%$ ) of the organic matter produced by phytoplankton is channeled through bacteria (Troncoso et al. 2003), making the microbial loop an important pathway for the recycling of organic matter in the upwelling water column. We found a correlation between the bacterial growth rate and Chl $a$ concentration (Fig. 7) but not bacterial growth rate and primary production (Table 1), which is not unusual for oligotrophic environments, especially in this region. The relationship between bacterial activity and phytoplankton production may be blurred or shifted by other processes. For example, changes in bacterial community structure (Schultz and Ducklow 2000) may change how organic substrates are utilized. Bacterial utilization of DOC and POC from turbulence and the upward displacement of water as well as temporal lags between phytoplankton production and bacterial utilization will obscure such relationships.

In oceanic upwelling systems larger algal species, especially diatoms, often dominate the phytoplankton community (Lassiter et al. 2006). However, previous studies observed that the smaller phytoplankton size fractions showed a faster response to the upwelling events than the larger size fractions (Lips and Lips 2010; Selph et al. 2011). Likewise, other studies report that Synechococcus spp. varies positively with $\mathrm{Chl} a$, which could dominate the phytoplankton community response in a coastal upwelling system (Garrison et al. 2000; Tsai et al. 2010b). Conventional thinking is represented by $\mathrm{Li}$ (2002), who found inverse relationships between picoplankton cell abundance and biomass relative to total Chl $a$ values from a series of Atlantic Ocean studies, whereas small nanoplankton were relatively invariant across the orders of magnitude of Chl $a$ concentration. More recently, it has been reported that there is a negative trend in picoplankton cell reduction under eutrophic conditions in three coastal systems south of the Iberian Peninsula (Echevarría et al. 2009). Ning et al. (2000) observed that the Synechococcus spp. biomass component became significant during periods of low phytoplankton biomass. Our observation of the upwelling area is also consistent with the notion that the Synechococcus spp. component of biomass becomes significant during periods of low phytoplankton biomass (Ning et al. 2000).

It is known that nanoflagellates influence the abundance of bacteria and picophytoplankton by grazing (James 


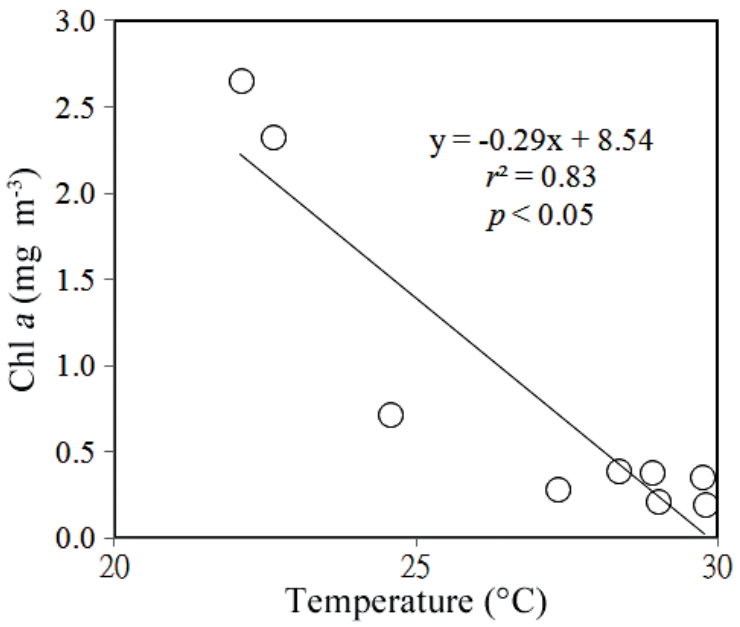

Fig. 9. Relationship between $\mathrm{Chl} a$ concentration and surface water temperature during the study period.

and Hall 1995; Tsai et al. 2008; Tsai et al. 2010b) and that grazing by nanoflagellates on bacteria and picophytoplankton serves as an essential link in the transfer of carbon to higher trophic levels. From our experiments, the significant, albeit weak, positive correlation of HNF biomasses with the picoplankton biomass (bacterial and Synechococcus spp. biomass) is an indication of the potential importance of food availability in the regulation of nanoflagellate abundance (Fig. 6). Furthermore, the overall variability in the relationship between picoplankton and nanoflagellates may reflect changes in the physical and chemical environment. Changing light, temperature and nutrient regimes will affect picoplankton production as well as changes in the rate of production when combined with increased nanoflagellate grazing. Furthermore, it is now well known that dinoflagellates, ciliates and metazooplankton are recognized predators on nanoflagellates, and impact nanoflagellate abundance (Suzuki et al. 1998; Wieltschnig et al. 1999; Berglund et al. 2005). In this upwelling region, a study found that ciliate community grazed about $43 \%$ of nanoflagellate production (Chen et al. 2012). Therefore, these ciliates may play an important role linking the nanoflagellate carbon source to higher trophic levels in the southern ECS.

Estimates of nanoflagellate grazing in the upwelling region we studied are also scarce. If we measured grazing rates of the total nanoflagellate assemblage on bacteria and Synechococcus spp., nanoflagellates would remove an average of $68 \%$ of the bacteria and $41 \%$ of the Synechococcus spp. production (Fig. 8). Similar results have also been found for the northern Humboldt Current System upwelling area, where there was higher grazing pressure on bacteria than cyanobacteria (Cuevas and Morales 2006). We found an imbalance between picoplankton production and nanoflagellate grazing in this study. Estimates of the impact of ciliate grazing suggest that they can control phytoplankton production (Verity et al. 1993) and play a significant role in the fate of bacteria (Stelfox-Widdicombe et al. 2000).

In summary, in the upwelling area of the southern ECS system we found a positive and significant correlation between $\mathrm{Chl} a$ concentrations and bacterial growth rates. These findings also suggest that food availability exerts a great influence in the regulation of nanoflagellate abundance. The results of this study highlight the potentially important role that the nutrient supply associated with upwelling inputs to surface waters accounting for a significant fraction of variability in phytoplankton growth and in regulating the growth of picoplankton and nanoplankton in the southern ECS.

Acknowledgments This study was supported by a grant (NSC 99-2611-M-019-015) from the National Science Council, ROC. We are most grateful to Mr. James Steed for his language editing and comments on the manuscript.

\section{REFERENCES}

Agawin, N. S. R. and S. Agustí, 1997: Abundance, frequency of dividing cells and growth rates of Synechococcus sp. (cyanobacteria) in the stratified Northwest Mediterranean Sea. J. Plankton Res., 19, 1599-1615, doi: 10.1093/plankt/19.11.1599. [Link]

Agawin, N. S. R., C. M. Duarte, and S. Agustí, 2000: Nutrient and temperature control of the contribution of picoplankton to phytoplankton biomass and production. Limnol. Oceanogr., 45, 591-600, doi: 10.4319/ lo.2000.45.3.0591. [Link]

Azam, F. and R. E. Hodson, 1977: Size distribution and activity of marine microheterotrophs. Limnol. Oceanogr., 22, 492-501, doi: 10.4319/lo.1977.22.3.0492. [Link]

Azam, F., T. Fenchel, J. G. Field, J. S. Gray, L. A. MeyerReil, and F. Thingstad, 1983: The ecological role of water-column microbes in the sea. Mar. Ecol. Prog. Ser., 10, 257-263, doi: 10.3354/meps010257. [Link]

Bak, R. P. M. and G. Nieuwland, 1993: Patterns in pelagic and benthic nanoflagellate densities in the coastal upwelling system along the Banc d'Arguin, Mauritania. Hydrobiologia, 258, 119-131, doi: 10.1007/ BF00006191. [Link]

Berglund, J., K. Samuelsson, T. Kull, U. Müren, and A. Andersson, 2005: Relative strength of resource and predation limitation of heterotrophic nanoflagellates in a low-productive sea area. J. Plankton Res., 27, 923-935, doi: 10.1093/plankt/fbi067. [Link]

Bode, A., J. A. Botas, and E. Fernández, 1997: Nitrate storage by phytoplankton in a coastal upwelling environment. Mar. Biol., 129, 399-406, doi: 10.1007/ s002270050180. [Link]

Børsheim, K. Y. and G. Bratbak, 1987: Cell volume to cell carbon conversion factors for a bacterivorous Monas sp. enriched from seawater. Mar. Ecol. Prog. Ser., 36, 
171-175, doi: 10.3354/meps036171. [Link]

Chen, J. Y., A. Y. Tsai, G. C. Gong, and K. P. Chiang, 2012: Grazing pressure by ciliates on the nanoflagellate community in a subtropical Pelagic continental shelf ecosystem: Small ciliates (of $<45 \mu \mathrm{m}$ ) are major consumers of the nanoflagellate community. Zool. Stud., 51, 1308-1318.

Chiang, K. P., F. K. Shiah, and G. C. Gong, 1997: Distribution of summer diatom assemblages in and around a local upwelling in the East China Sea northeast of Taiwan. Bot. Bull. Acad. Sin., 38, 121-129.

Christaki, U., F. Van Wambeke, and J. R. Dolan, 1999: Nanoflagellates (mixotrophs, heterotrophs and autotrophs) in the oligotrophic eastern Mediterranean: Standing stocks, bacterivory and relationships with bacterial production. Mar. Ecol. Prog. Ser., 181, 297-307, doi: 10.3354/meps 181297. [Link]

Cuevas, L. A. and C. E. Morales, 2006: Nanoheterotroph grazing on bacteria and cyanobacteria in oxic and suboxic waters in coastal upwelling areas off northern Chile. J. Plankton Res., 28, 385-397, doi: 10.1093/ plankt/fbi124. [Link]

Cuevas, L. A., G. Daneri, B. Jacob, and P. Montero, 2004: Microbial abundance and activity in the seasonal upwelling area off Concepción $\left(\sim 36^{\circ} \mathrm{S}\right)$, central Chile: A comparison of upwelling and non-upwelling conditions. Deep-Sea Res. Part II-Top. Stud. Oceanogr., 51, 2427-2440, doi: 10.1016/j.dsr2.2004.07.026. [Link]

Echevarría, F., L. Zabala, A. Corzo, G. Navarro, L. Prieto, and D. Macías, 2009: Spatial distribution of autotrophic picoplankton in relation to physical forcings: The Gulf of Cádiz, Strait of Gibraltar and Alborán Sea case study. J. Plankton Res., 31, 1339-1351, doi: 10.1093/plankt/fbp070. [Link]

Eppley, R. W., 1972: Temperature and phytoplankton growth in the sea. Fish Bull., 70, 1063-1085.

Falkowski, P. G., 1981: Light-shade adaptation and assimilation numbers. J. Plankton Res., 3, 203-216, doi: 10.1093/plankt/3.2.203. [Link]

Garrison, D. L., M. M. Gowing, M. P. Hughes, L. Campbell, D. A. Caron, M. R. Dennett, A. Shalapyonok, R. J. Olson, M. R. Landry, S. L. Brown, H. B. Liu, F. Azam, G.F. Steward, H. D. Ducklow, and D. C. Smith, 2000: Microbial food web structure in the Arabian Sea: A US JGOFS study. Deep-Sea Res. Part II-Top. Stud. Oceanogr., 47, 1387-1422, doi: 10.1016/S09670645(99)00148-4. [Link]

Gong, G. C., C. Z. Shyu, W. H. Shih, and K. K. Liu, 1992: Temperature fluctuation of the cold water off northern Taiwan: June-December, 1990. Acta Oceanogr. Taiwan., 28, 118-127. (in Chinese)

Gong, C. C., Y. L. Lee Chen, and K. K. Liu, 1996: Chemical hydrography and chlorophyll a distribution in the East China Sea in summer: Implications in nutri- ent dynamics. Cont. Shelf Res., 16, 1561-1590, doi: 10.1016/0278-4343(96)00005-2. [Link]

Gradinger, R., T. Weisse, and T. Pillen, 1992: Significance of picocyanobacteria in the Red Sea and the Gulf of Aden. Bot. Mar., 35, 245-250.

Hanson, R. B., M. T. Alvarez-Ossorio, R.Cal, M. J. Campos, M. Roman, G. Santiago, M. Varela, and J. A. Yoder, 1986: Plankton response following a spring upwelling event in the Ria de Arosa, Spain.Mar. Ecol.Prog.Ser., 32, 101-113, doi: 10.3354/meps032101. [Link]

Harrison, W. G., T. Platt, R. Calienes, and N. Ochoa, 1981: Photosynthetic parameters and primary production of phytoplankton populations off the northern coast of Peru. In: Richards, F. A. (Ed.), Coastal Upwelling, American Geophysical Union, Washington. D. C., 303-311.

Hill, J. K. and P. A. Wheeler, 2002: Organic carbon and nitrogen in the northern California current system: Comparison of offshore, river plume, and coastally upwelled waters. Prog. Oceanogr., 53, 369-387, doi: 10.1016/S0079-6611(02)00037-X. [Link]

Iriarte, A. and D. A. Purdie, 1994: Size distribution of chlorophyll $a$ biomass and primary production in a temperate estuary (Southampton Water): The contribution of photosynthetic picoplankton. Mar. Ecol. Prog. Ser., 115, 283-297.

James, M. R. and J. A. Hall, 1995: Planktonic ciliated protozoa: Their distribution and relationship to environmental variables in a marine coastal ecosystem. J. Plankton Res., 17, 659-683, doi: 10.1093/plankt/17.4.659. [Link]

Jiao, N., Y. Yang, N. Hong, Y. Ma, S. Harada, H. Koshikawa, and M. Watanabe, 2005: Dynamics of autotrophic picoplankton and heterotrophic bacteria in the East China Sea. Cont. Shelf Res., 25, 1265-1279, doi: 10.1016/j.csr.2005.01.002. [Link]

Kana, T. M. and P. M. Glibert, 1987: Effect of irradiances up to $2000 \mu \mathrm{E} \mathrm{m}^{-2} \mathrm{~s}^{-1}$ on marine Synechococcus WH7803I. Growth, pigmentation, and cell composition. DeepSea Res. Part I-Oceanogr. Res. Pap., 34, 479-495, doi: 10.1016/0198-0149(87)90001-X. [Link]

Lassiter, A. M., F. P. Wilkerson, R. C. Dugdale, and V. E. Hogue, 2006: Phytoplankton assemblages in the CoOPWEST coastal upwelling area. Deep-Sea Res. Part IITop. Stud. Oceanogr., 53, 3063-3077, doi: 10.1016/j. dsr2.2006.07.013. [Link]

Lee, S. and J. A. Fuhrman, 1987: Relationships between biovolume and biomass of naturally derived marine bacterioplankton. Appl. Environ. Microbiol., 53, 1298-1303.

Li, W. K. W. 2002: Macroecological patterns of phytoplankton in the northwestern North Atlantic Ocean. Nature, 419, 154-157, doi: 10.1038/nature00994. [Link]

Lips, I. and U. Lips, 2010: Phytoplankton dynamics affected by the coastal upwelling events in the Gulf of Finland in July-August 2006. J. Plankton Res., 32, 1269-1282, doi: 10.1093/plankt/fbq049. [Link] 
Liu, K. K., Z. L. Lai, G. C. Gong, and F. K. Shiah, 1995: Distribution of particulate organic matter in the southern East China Sea: Implications in production and transport. Terr. Atmos. Ocean. Sci., 6, 27-45.

Malone, T. C. and P. J. Neale, 1981: Parameters of lightdependent photosynthesis for phytoplankton size fractions in temperate estuarine and coastal environments. Mar. Biol., 61, 289-297, doi: 10.1007/BF00401568. [Link]

Neuer, S. and T. J. Cowles, 1994: Protist herbivory in the Oregon upwelling system. Mar.Ecol. Prog. Ser., 113, 147-162, doi: 10.3354/meps113147. [Link]

Ning, X., J. E. Cloern, and B. E. Cole, 2000: Spatial and temporal variability of picocyanobacteria Synechococcus sp. in San Francisco Bay. Limnol. Oceanogr., 45, 695-702, doi: 10.4319/lo.2000.45.3.0695. [Link]

Parsons, T. R., Y. Maita, and C. M. Lalli, 1984: A Manual of Chemical and Biological Methods for Seawater Analysis, Pergamon Press, Oxford, 173 pp.

Porter,K.G. and Y.S.Feig, 1980: The use of DAPI for identifying and counting aquatic microflora. Limnol. Oceanogr., 25, 943-948, doi: 10.4319/lo.1980.25.5.0943. [Link]

Ryther, J. H., 1969: Photosynthesis and fish production in the sea. Science, 166, 72-76, doi: 10.1126/ science.166.3901.72. [Link]

Sanders, R. W., U. G. Berninger, E. L. Lim, P. F. Kemp, and D. A. Caron, 2000: Heterotrophic and mixotrophic nanoplankton predation on picoplankton in the Sargasso Sea and on Georges Bank. Mar. Ecol. Prog. Ser., 192, 103-118, doi: 10.3354/meps192103. [Link]

Schultz, C. E. Jr. and H. Ducklow, 2000: Changes in bacterioplankton metabolic capabilities along a salinity gradient in the York River estuary, Virginia, USA. Aquat. Microb. Ecol., 22, 163-174, doi: 10.3354/ame022163. [Link]

Selph, K. E., M. R. Landry, A. G. Taylor, E. J. Yang, C. I. Measures, J. Yang, M. R. Stukel, S. Christensen, and R. R. Bidigare, 2011: Spatially-resolved taxonspecific phytoplankton production and grazing dynamics in relation to iron distributions in the Equatorial Pacific between 110 and $140^{\circ} \mathrm{W}$. Deep-Sea Res. Part II-Top. Stud. Oceanogr., 58, 358-377, doi: 10.1016/j. dsr2.2010.08.014. [Link]

Sherr, E. B. and B. F. Sherr, 2002: Significance of predation by protists in aquatic microbial food webs. Anton. Leeuw., 81, 293-308, doi: 10.1023/A:1020591307260. [Link]

Sherr, E. B., B. F. Sherr, and P. A. Wheeler, 2005: Distribution of coccoid cyanobacteria and small eukaryotic phytoplankton in the upwelling ecosystem off the Oregon coast during 2001 and 2002. Deep-Sea Res. Part II-Top. Stud. Oceanogr., 52, 317-330, doi: 10.1016/j. dsr2 2004.09.020. [Link]
Stelfox-Widdicombe, C. E., E. S. Edwards, P. H. Burkill, and M. A. Sleigh, 2000: Microzooplankton grazing activity in the temperate and sub-tropical NE Atlantic: Summer 1996. Mar. Ecol. Prog. Ser., 208, 1-12, doi: 10.3354/meps208001. [Link]

Suzuki, T., N. Yamada, and A. Taniguchi, 1998: Standing crops of planktonic ciliates and nanoplankton in oceanic waters of the western Pacific. Aquat.Microb. Ecol., 14, 49-58.

Troncoso, V. A., G. Daneri, L. A. Cuevas, B. Jacob, and P. Montero, 2003: Bacterial carbon flow in the Humboldt Current System off Chile. Mar. Ecol. Prog. Ser., 250, 1-12, doi: 10.3354/meps250001. [Link]

Tsai, A. Y., K. P. Chiang, J. Chang, and G. C. Gong, 2005: Seasonal diel variations of picoplankton and nanoplankton in a subtropical western Pacific coastal ecosystem. Limnol. Oceanogr., 50, 1221-1231, doi: 10.4319/lo.2005.50.4.1221. [Link]

Tsai, A. Y., K. P. Chiang, J. Chang, and G. C. Gong, 2008: Seasonal variations in trophic dynamics of nanoflagellates and picoplankton in coastal waters of the western subtropical Pacific Ocean. Aquat. Microb. Ecol., 51, 263-274, doi: 10.3354/ame01196. [Link]

Tsai, A. Y., G. C. Gong, R. W. Sanders, C. J. Wang, and K. P. Chiang, 2010a: The impact of the Changjiang River plume extension on the nanoflagellate community in the East China Sea. Estuar. Coast. Shelf Sci., 89, 2130, doi: 10.1016/j.ecss.2010.05.005. [Link]

Tsai, A. Y., G. C. Gong, R. W. Sanders, C. F. Chao, and K. P. Chiang, 2010b: Microbial dynamics in an oligotrophic bay of the western subtropical Pacific: Impact of short-term heavy freshwater runoff and upwelling. J. Oceanogr., 66, 873-883, doi: 10.1007/s10872-0100071-3. [Link]

Tsai, A. Y., G. C. Gong, K. P. Chiang, C. F. Chao, and H. R. Guo, 2011: Long-term (1998-2007) trends on the spatial distribution of heterotrophic ciliates in the East China Sea in summer: Effect of the Three Gorges Dam construction. J. Oceanogr., 67, 725-737, doi: 10.1007/ s10872-011-0069-5. [Link]

Vargas, C. A. and H. E. González, 2004: Plankton community structure and carbon cycling in a coastal upwelling system. II. Microheterotrophic pathway. Aquat.Microb. Ecol., 34, 165-180, doi: 10.3354/ame034165. [Link]

Vargas, C. A., R. A. Martínez, L. A. Cuevas, M. A. Pavez, C. Cartes, H. E. González, R. Escribano, and G. Daneri, 2007: The relative importance of microbial and classical food webs in a highly productive coastal upwelling area. Limnol. Oceanogr., 52, 1495-1510, doi: 10.4319/ 10.2007.52.4.1495. [Link]

Verity, P. G., D. K. Stoecker, M. E. Sieracki, and J. R. Nelson, 1993: Grazing, growth and mortality of microzooplankton during the 1989 North Atlantic spring bloom at $47^{\circ} \mathrm{N}, 18^{\circ} \mathrm{W}$. Deep-Sea Res. Part I-Oceanogr. 
Res. Pap., 40, 1793-1814, doi: 10.1016/0967-0637(93)90033-Y. [Link]

Wetz, M. S. and P. A. Wheeler, 2004: Response of bacteria to simulated upwelling phytoplankton blooms. Mar. Ecol. Prog. Ser., 272, 49-57, doi: 10.3354/ meps272049. [Link]

Wieltschnig, C., P. Wihlidal, T. Ulbricht, A. K. T. Kirschner, and B. Velimirov, 1999: Low control of bacterial production by heterotrophic nanoflagellates in a eutrophic backwater environment. Aquat. Microb. Ecol., 17,
77-89, doi: 10.3354/ame017077. [Link]

Worden, A. Z., J. K. Nolan, and B. Palenik, 2004: Assessing the dynamics and ecology of marine picophytoplankton: The importance of the eukaryotic component. Limnol. Oceanogr., 49, 168-179, doi: 10.4319/ 10.2004.49.1.0168. [Link]

Wright, R. T. and R. B. Coffin, 1984: Measuring microzooplankton grazing on planktonic marine bacteria by its impact on bacterial production. Microb. Ecol., 10, 137149, doi: 10.1007/BF02011421. [Link] 